\title{
Değişim Yönetimi Uygulamalarında Başarı Faktörlerinin Belirlenmesi ve Uygulamaya Yönelik Bir Model Önerisi
}

\author{
Gül Eser ${ }^{\mathrm{a}}$
}

\begin{abstract}
Öz: Değişim yönetimi alanında en çok akla gelen modeller Lewin (1951) ve Kotter (1995) tarafindan önerilmiş olan değişim yönetimi modelleridir. Bu modeller Türk yazınında da kabul görmüş olmakla beraber, incelendiklerinde oldukça genel ifadelerden oluştukları görülmektedir. Bu modeller kullanılarak bir firmada gerçekleşecek olan değişim yönetimi uygulamalarının düzenlenmesi pek gerçekçi gözükmemektedir. Bu çalışmada değişim yönetimi alanında yürütülmüş olan araştırmaların sonuçlarından yola çıkarak, değişim yönetiminde başarı faktörlerinin belirlenmesi ve bir değişim yönetimi modelinin ortaya koyulması hedeflenmiştir. Bu amaçla Yüksek Öğretim Kurumu (YÖK) ulusal tez merkezi veri tabanında ve TUBITAK Ulusal Akademik Ağ ve Bilgi Merkezi (ULAKBIM) Sosyal ve Beşeri Bilimler Veri Tabanı Dergi Listesinde, "sosyal ve beşeri bilimler (genel)" ve "ekonomi ve işletme" başlıkları altında yer alan bilimsel dergilerin arşivleri "değişim" ve "değişim yönetimi" anahtar sözcükleri ile taranmıştır. Bu çalışma kapsamında toplamda 72 olmak üzere 31 makale ve 41 teze ulaşılmış ve gerçekten değişim yönetimi sürecini inceleyen 25 çalışmanın sonucundan hareketle değişim yönetiminde başarı unsurları iletişim, potansiyel direnişçiler, insan kaynakları, liderlik, paylaşılan vizyon, teşvik, değişim ekibi, değişim kültürü olarak belirlenmiştir. Değişim yönetimi uygulama sürecinde ise mevcut durumun tespiti, değişimin ana hatlarının belirlenmesi, izleme ve sabitleme olmak üzere 4 temel adıma ulaşılmıştır.
\end{abstract}

Anahtar Sözcükler: Değişim, Değişim Yönetimi, Değişim Modeli, Değişim Başarı Faktörleri

JEL Sınıflandırması: M10, M19

\section{Defining Key Factors for Successful Change Management and A New Model Proposal}

\begin{abstract}
Change management models proposed by Lewin (1951) and Kotter (1995) are well known in the literature. These models are also well accepted in Turkish literature as well; however they include very broad explanations. It is not clear whether these models can be used as a guide in practice. This study aims to analyze studies conducted in the field of change management in order to determine success indicators for change management practices and suggest a new change management model. For this purpose authorized dissertations and thesis in database of National Thesis Archive at the Council of Higher Education Center and articles published in journals Indexed within ULAKBIM National database were reviewed with keywords "change" and "change management". 72 relevant studies were analyzed, 31 of which are articles and 41 are thesis and dissertations, 25 of which examined a real change process within an organization. Considering these 25 studies' result, success indicators for change management are defined as follows; communication, potential resistors, human resources department, leadership, shared vision, incentive, team and culture. The proposed change management model consists of 4 main processes named evaluation of the present state, defining outline for change, monitoring and freezing.
\end{abstract}

Keywords: Change, Change Management, Change Model, Change Success Indicators

JEL Classification: M10, M19 


\section{Giriş}

En sık rastlanan ve en genel tanımı ile değişim; "bir durumdan yeni bir duruma geçmeyi" ifade etmektedir. Bu tanımdan hareket edilecek olursa, değişim yönetiminin oldukça kapsamlı bir alan olduğu anlaşılmaktadır. Bir tanım kapsamlı hale geldikçe onu tanımlama ve ölçme sorunu da beraberinde gelmektedir. Değişim yönetimine ilişkin bu sorun Kang (2015) tarafindan "değişim yönetimi" nin geniş bir kullanım alanı olan şemsiye bir kavram olması nedeniyle araştırmacı ve uygulamacılar tarafindan ortak kabul gören bir tanımının olmadığı şeklinde ortaya koyulmuştur.

Değişimin çok genel bir ifade taşıması kapsam bakımından farklı şekillerde tanımlanarak sınıflandırılmasına yol açmıştır. Örneğin niteliksel (yapısal, stratejik, kültürel değişim) ve niceliksel değişim şeklinde çeşitli sınıflandırmalar yapılmıştır (Fink vd., 2014). Bunun dışında değişim yönetimi; planlı-plansız değişme, makro-mikro değişim, zamana yayılmış-ani değişim, proaktif-reaktif değişim, geniş-dar kapsamlı değişim, aktif-pasif değişim, adım adım-radikal değişim şeklinde de sınıflandırılmaktadır (Koçel, 1999 içinde illğan, 2008). Bu sınıflandırmalar dışında değişim yönetimi, yönetim alanında kişilik (Kara vd., 2013), beşeri sermaye (Paksoy ve Özbezek, 2013), bilgi teknolojileri (Ekinci, 2006), işletme performansı (Gökmen, 2010), değişim ajanlarının rolleri (Özmen ve Sönmez, 2007), kriz (Öztürk ve Ünlücan, 2001) gibi birçok değişken ile ilişkilendirilerek araştırma konusu yapılmıştır.

Günümüzün belirsiz ekonomik ikliminde çoğu örgüt hayatta kalmak için değişmek durumunda kalmaktadır. Bu noktada örgütler hem küresel hem yerel ve ulusal düzeyde ortaya çıkan değişimlere ayak uydurmaya çabalamaktadırlar. Ancak değişim yönetimi hem insanları ikna etmenin zorluğu hem de uzun süren bir süreç olması bakımından zorlu bir dönemi ifade etmektedir. Değiş̧im uygulamalarının başarısız olmasının maliyeti ise oldukça yüksektir. Bu maliyetler pazardaki pozisyonunu kaybetmekten, paydaşların nezdinde itibar kaybetmeye; yönetim ve personelde motivasyon kaybıma hatta kilit çalışanların kaybına kadar uzanabilmektedir (Edmonds, 2011).

Her ne kadar değişim yönetimi uygulamalarının başarısı bu derece önemli olsa da araştırmalara göre projelerin yalnızca \%41'i planlanan zaman, bütçe ve kalite kapsamında amacına ulaşmıştı. Projelerin neredeyse \%60'ı ise amaçlarını tam olarak ulaşmak konusunda başarısızlığa uğramıştı. Projelerin \%15'i ise ya tamamen başarısız olmuş ya da yönetim tarafindan durdurulmuştur (Jorgensen, 2009). Skogland ve Hansen (2017) de benzer şekilde örgütsel değişim yönetimi alanında, örgütsel değişim çabalarının \%70'inin başarısızlıkla sonuçlandığının genel kabul gören bir istatistiki oran olduğunu ifade etmektedirler.

Değişim uygulamalarına ilişkin bu genel tablo, değişim yönetimi alanında çalışan araştırmacı ve uygulayıcıları değişim yönetimi uygulamalarında başarı ve başarısızlığa yol açan unsurları belirlemeye ve bu yönde öneriler sunmaya yöneltmiştir. Bu araştırmanın temel amacı da; Türk yazınında değişim yönetimini alanında yürütülmüş araştırmalardan yola çıkarak Türk kültürüne özgü bir değişim yönetimi modeli ortaya koymaktır. Bu bağlamda, izinli yüksek lisans ve doktora tezleri ve Ulusal Akademik Ağ ve Bilgi Merkezi (ULAKBIM) Ulusal veri tabanında yer alan dergiler "değişim" ve "değişim yönetimi" anahtar kelimesi ile taranmış ve 31'i makale ve 41'i tez olmak üzere toplamda 72 yayına ulaşılmıştır. Bu çalışmalar öncelikle yayın yılı, yayın türü, yöntem, ölçeklere ilişkin bilgiler (geliştiren, geçerlilik ve güvenilirlik, boyutlar), örnekleme ilişkin özellikler (sektör, sayı, şehir), bağımlı ve bağımsız değişkenler, araştırma bulguları ve araştırmacıların önerileri bakımından detaylı bir şekilde incelenmiş, ardından bir değişim sürecini inceleyen 14 tez ve 11 makalenin toplam 25 araştırmanın sonuç ve önerilerinden yola çıkarak bir model önerisi ortaya koyulmuştur. Türk yazınında yer alan araştırmaların incelenmesi ile değişim yönetimi konusunda, kendi kültürümüze özgü temel başarı unsurlarını belirlemek ve bu süreçte dikkat edilecek noktalara dikkat çekmek hedeflenmektedir.

\section{Kavramsal Çerçeve: Değişim Yönetimi}

Örgütsel değişim kavramı zaman içerisinde değişmiş ve bu alanda yeni yaklaşımlar ortaya çıkmıştır. Geçmişte değişim yönetimi; ajandası, yani başlangıcı ve bitişi belli olan bir program ya da proje olarak ele alınırken, artık örgütlerin dinamik ve çalkantılı bir çevreye uyum sağlamaya çalışırken içinde bulundukları her yeri kaplayan ve süregiden bir süreç olarak görülmektedir. Yine geçmişte değişim yönetimi tepe yöneticisi tarafindan yürütülen bir değişim olarak algılanmakta ve geri kalan üyeler tarafindan sorgusuz sualsiz kabul ve 
takip edilmesi beklenmekte iken, zamanla değişim hem yukarıdan aşağıya hem de aşağıdan yukarıya çift yönlü şekilde ve örgüt üyelerinin büyük kısmının katılımı ile gerçekleştirilen bir süreç halini almıştır (Pitt vd., 2001).

Örgütsel değişime ilişkin tanımlar incelendiğinde de bu yeni yaklaşımın etkilerini görmek mümkündür. Örneğin Sabuncuoğlu ve Tüz (1995) örgütsel değişimi, örgütlerin yapı olarak bulundukları çevreye uyarlanmaları olarak, Töremen (2002) ise yapı, süreç ve davranışlardaki değişme anlamında ele almaktadır. Vardar (2001) ise değişim yönetimini mevcut durumun, iletişim halinde olunan çevre şartlarının intiyaçları karşısında yetersiz kalması durumunda, kurumları yeniden yapılandıracak düzeyde yenilik üretmeye karar verme ve bunu uygulama süreci olarak tanımlamıştır (Altındiş vd., 2011). Hussey (1998) ise örgütleri değişime yönlendiren en önemli unsurları; rekabet (kaçınılmazdır ve en sık karşılaşılan unsurdur), müşteriler (beklentilerin değişmesi ve talepkar hale gelmeleri), teknoloji (sürekli yenilenme) ve yeni düzenlemeler olarak ele almaktadır. Bu bağlamda, Alıç (1990) örgütsel değişimi; örgütün alt sistemlerinde, alt sistemlerin birbirleriyle, örgütle ve çevreyle geliştirdiği ilişki ve etkileşim kalıplarında, örgütün çevresiyle olan ilişki ve etkileşim biçimlerinde görülen her türlü değişme olarak tanımlamaktadır (Güçlü ve Şehitoğlu, 2006).

Araştırmacıların örgütsel değişim yönetimine ilişkin tanımları dikkate alınınca, temelde konunun örgütün çevresine uyum sağlama süreci ile ilgili olduğu görülmektedir. Bu noktadan hareketle örgütü değişime zorlayan temel neden örgütün çevresinde meydana gelen değişimlerdir. Örgütün çevresindeki değişimlere uyum sağlamasının ardında yatan neden ise varlığını sürdürmek ve mevcut durumdan daha iyi bir pozisyona gelmektir. Günümüzde sürekli değişen çevre koşulları dikkate alındığında, örgüt içinde meydana gelen değişimin sonu gelmeyen dinamik bir süreç olduğunu söylemek mümkündür. Bu durum, her örgütün değişime uyum sağlamayı kolaylaştıran bir kültüre sahip olması gerektiği anlamına gelmektedir. Edmonds (2011), örgütsel değişime yol açan çevresel unsurları; hükümet ve kanunlarda meydana gelen değişiklikler, küresel pazarlara giriş baskıları ve yeni süreçlerin ortaya çıkışı şeklinde sıralamaktadır. Bunların dışında birleşme ve satın almalar, yapısal değişiklikler, çıkış stratejileri ve reorganizasyon da değişime yol açan unsurlar arasında sıralanmaktadır (Edmonds, 2011).

Örgütsel değişim yönetimi alanında kendilerine atfedilen önem nedeni ile dikkat çeken üç tür değişimden söz etmek mümkündür. Bunlar 1980 'lerde yeni teknolojilerin ortaya çıkışı, toplam kalite uygulamaları ve değişim mühendisliğidir. 1980 'lerde bilgisayar ve bilgisayar temelli süreçlerin örgütsel hayatta birçok alana girmesi ile beraber yürütülen araştırmalar, yeni teknolojilere ilişkin değişim projelerinin başarısızlık oranının yüzde 40 ile 70 arasında değiştiğini göstermektedir. 1980'lerin ortasında Avrupalı örgütler Toplam Kalite Yönetimini (TKY) benimsemeye başlamışlardır. Her ne kadar TKY uygulamaları Japon firmalarının başarı anahtarı gibi gözükse de battı firmalar bu uygulamayı tanıtma ve sürdürme konusunda zorluk yaşamışlardır. Bu alanda yapılan uygulamaların Amerika Birleşik Devletleri'nde (ABD) yüzde 90 Avrupa'da ise yüzde 80 oranda başarısızlıkla sonuçlandığı ifade edilmektedir. Değişim mühendisliği uygulamaları da benzer şekilde beklenen başarıyı elde edememiş hatta yöntemin kurucusu M.Hammer bile bu yöntemin örgütleri başlangıçtan daha kötü bir noktaya getirdiğini ifade etmiştir (Burnes, 2003). Bu yöntemlere ilişkin yaşanan hüsran ve başarısızlık oranının yüksekliği değişim yönetimi uygulamalarında kritik unsurlar olduğuna işaret etmektedir. Bu amaçla değişim yönetimi konusu ile ilgilenen birçok araştırmacının iki önemli alana odaklandığını görmek mümkündür. Bunlar; değişimin başarılı olmasının önündeki engeller ve değişim sürecinin başarılı olmasını sağlayacak unsurların belirlenmesidir. Bu araştırmanın konusu da yazından hareketle, değişim yönetiminde başarı unsurlarının belirlenmesi ve değişim yönetimi uygulamalarının ne şekilde gerçekleştirilebileceği konusunda uygulamaya dönük bilginin üretilmesidir.

Değişim yönetimi alanında uygulamaya yönelik olarak önerilmiş alanında en eski ve bilinen model Kurt Lewin (1951) tarafindan önerilmiş olan "çözme-değişim-yeniden dondurma" modelidir. Bu modelin oldukça mekanik bir yaklaşıma sahip olduğunu söylemek mümkündür. Bu modelde çözme aşaması, değişime direnen ya da olumsuz tutuma sahip kişilerin değişimin gerekliliği konusunda ikna edildiği aşamadır. Değişim aşaması, değişim sürecinin uygulanmasını yani mevcut durumdan bir başka duruma geçilmesi durumunu ifade etmektedir. Yeniden dondurma başılılı son aşama ise değişimin sürekliliğini sağlayacak şekilde durumun sabitlenmesini ifade etmektedir (Koçel, 2003). 
Değişim yönetimi alanında, değişim uygulamalarının niçin başarısız olduklarını irdeleyerek, başarılı bir değişim yönetimi için bir model önerisi sunan Kotter (1995) ise, modelini 8 basamakta açıklamaktadır. Kotter' a göre örgütü dönüştürmek için; (1) bir ivedilik duygusu oluşturmak, (2) güçlü bir rehberlik koalisyonu biçimlendirmek, (3) bir vizyon yaratmak, (4) vizyonu iletmek, (5) diğerlerine vizyona göre hareket etme yetkisi vermek, (6) kısa vadeli kazanımları planlamak ve oluşturmak, (7) iyileştirmeleri pekiştirmek ve daha fazla değişim yaratmak, (8) yeni yaklaşımları kurumsallaştırmak gereklidir. Bu aşamaların her biri titizlikle uygulandığı takdirde değişim yönetiminin başarılı olması mümkün olacaktır.

Lewin ve Kotter'ın önerdikleri değişim modelleri dışında alan yazında başarılı değişim uygulamalarına yol göstermek için önerilen başka model önerileri de mevcuttur. Örneğin Jorgensen (2009), 1532 kilit uygulayıcı ile yürüttüğü araştırmasının sonucunda değişimin önündeki engelleri; zihniyet ve tutumlar, örgüt kültürü ve son olarak proje karmaşıklığının küçümsenmesi şeklinde sıralamıştır. Araştrmaya katılan değişim ajanları bu üç unsurun kaynak yetersizliğinden daha önemli sorunlar olduğunu ifade etmişlerdir. Bunun nedeni ise bu unsurların yönetim ve ölçümünün, iş süreçleri ve teknolojiye nazaran daha zor olması şeklinde açıklanmıştır. Araştırma sonuçlarına göre değişimin başarı unsurlar ise; üst yönetimin desteği, dürüst ve zamanında iletişim, değişimi destekleyen bir kültürün varlığı şeklinde sıralanmıştır. Burada da yine performans ölçümü, teşvikler ve yapı gibi unsurlardan ziyade değişimin yumuşak yanı olan davranış ve kültüre ait öğelerin kritik öneme sahip olmasına dikkat çekilmektedir. Bu nedenle değişim ajanları bu unsurları değişim sürecinin en başından itibaren ele almakta, dikkatle planlamakta ve titizlikle uygulamaktadırlar. Bu noktada değişimin planlı şekilde yapılmasının (planlanmayan değişime göre) değişimin başarı şansını anlamlı şekilde arttırdığı da araştırma bulguları arasındadır (Jorgensen, 2009).

Oakland ve Tanner (2007) ise değişim yönetimi yazınında 4 genel temanın baskın olduğunu belirtmişlerdir. Bunlardan ilki liderliktir. Liderlik yön belirleme, değişim sürecinde örgüte ilham verme ve değişimin uygulandığından emin olmak gibi unsurları içermektedir. İkinci ve liderlikle ilgili olan tema, gerekli olan değişim ihtiyacının tespit edilip tanımlanmasıdır. Bu tema genellikle finansal baskılarla ilişkili olmaktadır. Üçüncü tema ise yumuşak yönler olarak ifade edilen ve değişimin başarısı için gerekli olan insanlardır. Bu tema aynı zamanda örgüt kültürünü ve iyi iletişimi de kapsamaktadır. Dördüncü tema ise öğrenmedir. Bu tema örgüt dışından; uzmanlık, yetenekli kaynak, değişim yönetimine ilişkin bilgi ve deneyim sahibi olan bir kişiden danışmanlık almayı içermektedir. Buna göre araştırmacılar değişim yönetimi alanında en fazla üzerinde durulan unsurları liderlik, değişim ihtiyacının tespiti, insanlar ve öğrenme olarak ele almışladır. Benzer şekilde Manning (2012) de değişim yönetiminde kilit başarı temalarını tanımlamıştır. Bunlar; stratejik düşünme, liderlik, görev yönetimi, ilişkiler ve kaynaklar şeklinde sıralanmaktadır. Pitt vd. (2001) ise değişimin temelde iletilen bir unsur olduğu varsayımından hareketle, iletişim ve değişimi birbirinden ayrılmaz bir bütün olarak ele almakta ve değişim yönetimi uygulamalarının başarısında etkili iletişimin en önemli unsur olduğunu ifade etmektedirler.

Değişim yönetimi alanında önerilen bu modeller uygulayıcılara yol göstermesi bakımından önemli ve yararlı bilgiler sunmaktadır. Yukarıdaki açıklamalarda ele alınan ve değişim yönetimi alanında başarı unsurlarına dikkat çeken araştırmacıların önerileri dikkate alındığında genel olarak başarı unsurlarını; değişim sürecinin belirlenmesi, üst yönetimin desteği, stratejik düşünme, görev yönetimi, liderlik, değişim kültürü, ilişkiler ve kaynaklar, insanlar, öğrenme, iletişim şekilde sıralamak mümkündür.

Bu çalışmanın amacı da benzer şekilde Türk değişim yönetimi yazınında yer alan çalışmaların bulguları doğrultusunda ortaya çıkan başarı unsurlarını belirlemek ve bir model önerisini sunmaktır. Bu amaçla değişim yönetimi alanında hazırlanmış olan erişime açık yüksek lisans ve doktora tezleri ile ULAKBiM veri tabanında yer alan dergilerde değişim yönetimini konu alan makaleler detaylı şekilde incelenmiş, bu çalışmalardan hareketle yeni bir değişim yönetimi modeli ortaya koyulmuştur. Ayrıca çalışmaların incelenmesi sonucunda elde edilen bulgular yabancı ve Türk yazın doğrultusunda elde edilen sonuçlarla karşılaştırmalı olarak ortaya koyulmuştur. 


\section{Araştırma}

\subsection{Araştırmanın Örneklemi}

Yüksek Öğretim Kurumu (YÖK) ulusal tez merkezi veri tabanında günümüze kadar yazılmış izinli tüm yüksek lisans ve doktora tezleri "değişim yönetimi" anahtar kelimesi ile aranmış ve toplamda 41 teze erişilmiştir. Bu anahtar kelime ile ulaşılan tüm tezler araştırmaya dahil edilmiştir. Araştırmanın "değişim yönetimi" anahtar kelimesi ile sınırlı tutulmasının sebebi "değişim" kelimesinin oldukça geniş ve birçok alanı kapsayan bir sözcük olması ve farklı disiplinlerden eserleri de içermesidir. Bu çalışmanın esas amacı "değişim yönetimi" sürecini incelemek olduğundan tek bir anahtar sözcük yeterli görüşmüştür. ULAKBiM Sosyal ve Beşeri Veri Tabanı Dergi Listesinde, "sosyal ve beşeri bilimler (genel)" ve "ekonomi ve işletme" başlıkları altında yer alan bilimsel dergilerin arşivleri yine "değişim" ve "değişim yönetimi" başlıkları ile taranmış, bu arama sonucunda toplumsal değişim ya da değişim mühendisliği gibi spesifik alanlara özgü çalışmalar kapsam dışı bırakılmıştır. Dergilerin ana sayfalarında yer alan "arama" butonunda her zaman tüm eserlerin belirlenmesi mümkün olmadığından, arşivde yer alan tüm sayılarda yer alan makaleler tek tek incelenmiş ve "değişim yönetimi" alanı ile ilgili olanlar araştırmaya dahil edilmiştir. Bu inceleme sonucunda toplamda 36 yayına ulaşılmış, 5 yayın değişim yönetimi ile ilgili olmadığından kapsam dışı bırakılmıştır.

\subsection{Veri Analizi}

Araştırma kapsamında incelenen tüm çalışmalar Microsoft Excel programında hazırlanan bir tablo üzerinde, ortak kriterler bakımından değerlendirilmiştir. Bu tabloda; yayın yılı, yazarlar, araştırmanın türü (yüksek lisans tezi, doktora tezi ya da makale), araştırma yöntemi, kullanılan ölçek, ölçeği geliştiren araştırmacı, geçerlilik ve güvenilirlik çalışmaları, bağımlı ve bağımsız değişkenler, örneklem özelliği, örneklem sayısı, araştırmanın sonucu ve araştırmacıların önerileri gibi başıılar yer almaktadır. 72 çalışmanın tümü bu kriterler bakımından bu tabloya aktarılmış ve böylece alan yazınının genel görüntüsünün ortaya koyulmuştur.

\section{Bulgular}

Bu çalışmanın temel amacı değişim yönetimi modeli önerisi sunmak olsa da, Türk alan yazınında "değişim yönetimi" alanında yapılmış çalışmaların genel görüntüsünü ortaya koymak bakımından da önem taşımaktadır. Bu nedenle öncelikle araştırmalara ilişkin genel görünümü yansıtan, araştırmaların türü, yılı, yöntemi, kullanılan ölçekler, ölçekleri geliştiren araştırmacı, ölçeklerin geçerlilik ve güvenilirlik çalışması, araştrrmanın yürütüldüğü şehir ve sektör, bağımlı ve bağımsız değişkenlere ilişkin bilgiler sunulmuştur. Ardından gerçekten bir "değişim yönetim" sürecini ele alan çalışmaların bulguları ve önerileri doğrultusunda bir model önerisi sunulmuştur.

\section{1. Çalışmaların Türlerine Göre Dağılımı}

Tablo 1'de görüldüğü üzere araştırma kapsamında incelenen çalışmaların 10'u doktora tezi, 31'i yüksek lisans tezi ve $31^{\prime}$ i de makale niteliğinde çalışmadır.

Tablo 1. Çalışmaların Türlerine Göre Dağııımı

\begin{tabular}{ccc} 
Tür & Frekans & Yüzde \\
\hline Dr. Tezi & 10 & 13.8 \\
YL Tezi & 31 & 43.05 \\
Makale & 31 & 43.05 \\
\hline TOPLAM & 72 & 100,0
\end{tabular}




\section{2. Çalışmaların Yıllara Göre Dağılımı}

Tablo 2'de değişim yönetimi alanında yapılmış olan çalışmaların yıllara göre dağılımı sunulmuştur. Bu tabloya göre değişim yönetimi alanındaki çalışmalar 1996 yılında başlamış ve 1999 yılından sonra da kesintisiz bir şekilde devam etmiştir. Tablo 2'ye göre en fazla çalışmanın 8 çalışma ile 2008 yılına ait olduğu görülmektedir.

Tablo 2. Çalışmaların Yıllara Göre Dağııımı

\begin{tabular}{|c|c|c|}
\hline YIl & Frekans & Yüzde \\
\hline 1996 & 1 & 1,38 \\
\hline 1997 & 0 & 0,00 \\
\hline 1998 & 0 & 0,00 \\
\hline 1999 & 1 & 1,38 \\
\hline 2000 & 2 & 2,77 \\
\hline 2001 & 1 & 1,38 \\
\hline 2002 & 1 & 1,38 \\
\hline 2003 & 3 & 4,16 \\
\hline 2004 & 8 & 11,11 \\
\hline 2005 & 4 & 5,50 \\
\hline 2006 & 4 & 5,50 \\
\hline 2007 & 6 & 8,33 \\
\hline 2008 & 5 & 6,94 \\
\hline 2009 & 4 & 5,50 \\
\hline 2010 & 5 & 6,94 \\
\hline 2011 & 4 & 5,50 \\
\hline 2012 & 5 & 6,94 \\
\hline 2013 & 4 & 5,50 \\
\hline 2014 & 6 & 8,33 \\
\hline 2015 & 3 & 4,16 \\
\hline 2016 & 4 & 5,50 \\
\hline 2017 & 1 & 1,38 \\
\hline OPLAM & 72 & 100,00 \\
\hline
\end{tabular}

\section{3.Çalışmaların Yöntem Bakımından Dağılımı}

İncelenen çalışmalar yöntem bakımından incelendiğinde araştırma içeren çalışmaların çoğunda yani $\% 62,5^{\prime}$ inde nicel yöntemin kullanıldığını görmekteyiz. Çalışmaların \%12,5'i nitel, \%4,1'i ise nitel ve nicel yöntemleri bir arada kullanmıştır. 15 çalışma (2'si yüksek lisans tezi) araştırma içermediğinden belirli bir yöntem de içermemektedir.

Tablo 3. Çalışmaların Yöntem Bakımından Dağııımı

\begin{tabular}{ccc} 
Tür & Frekans & Yüzde \\
\hline Nicel & 45 & 62,5 \\
Nitel & 9 & 12,5 \\
Nitel ve Nicel & 3 & 4,1 \\
Araştırma İçermemektedir & 15 & 20,83 \\
\hline TOPLAM & 72 & 100
\end{tabular}




\section{4. Ölçeği Geliştiren Araştırmacı Bakımından Çalışmaların Dağılımı}

Çalışmalarda kullanılan ölçekler, ölçekleri geliştiren araştırmacılar bakımından incelendiğinde, çalışmaların çoğunda \%39,58 kullanılan ölçeğin araştırmacı tarafindan geliştirildiğini görmekteyiz. Çalışmaların \%35,41'inde ise kullanılan ölçeğe ilişkin bir bilgi verilmemiştir. Geri kalan çalışmaların ölçekleri incelendiğinde alanda sıklıkla kullanılan bir ölçeğin olmadığı en fazla referans verilen değişim ölçeğinin Hammer (2003) tarafindan geliştirilen ölçek olduğu görülmektedir.

Tablo 4. Çalışmalarda Kullanılan Ölçeklerin Dağılımı

\begin{tabular}{|c|c|c|}
\hline Ölçeği Geliştiren & Frekans & Yüzde \\
\hline Araştırmacının Kendisi & 19 & 39,58 \\
\hline Yıldız (2009) & 2 & 4,16 \\
\hline Hammer (2003) & 2 & 4,16 \\
\hline Hammer vd. (2003) & 1 & 2,08 \\
\hline Everard ve Morris (1996) & 2 & 4,16 \\
\hline Keçecioğlu (2001) & 1 & 2,08 \\
\hline Helvacı (2012) & 1 & 2,08 \\
\hline Oreg (2003) & 1 & 2,08 \\
\hline Bostan (2009) & 1 & 2,08 \\
\hline Altan (1999) & 1 & 2,08 \\
\hline Belirtilmemiş & 17 & 35,41 \\
\hline TOPLAM & 48 & 100 \\
\hline
\end{tabular}

\subsection{Geçerlilik ve Güvenilirlik Analizi Bakımından Çalışmaların Dağııımı}

Ölçek kullanmış olan 48 çalışmanın \%50'sinde kullanılan ölçeğin geçerlilik ve güvenilirlik analizi araştırmacı tarafindan yürütülmüştür. $\% 45,83$ 'ünde ise bu bilgiye yer verilmemiştir. Çalışmaların yalnızca 2'sinde ise geçerlilik ve güvenilirlik analizi daha önce bir başka araştırmacı tarafindan yapılmış olan ölçekler kullanılmıştır.

Tablo 5. Geçerlilik ve Güvenilirlik Analizi

\begin{tabular}{ccc} 
Çalışmayı Yapan & Frekans & Yüzde \\
\hline Araştırmacının Kendisi & 24 & 50 \\
Başka Araştırmacı & 2 & 4,16 \\
Belirtilmemiş & 22 & 45,83 \\
& & \\
\hline TOPLAM & 48 & 100
\end{tabular}

\subsection{Araştırmanın Yürütüldüğü Şehir Bakımından Çalışmaların Dağılımı}

Ele alınan çalışmalar yürütüldükleri şehir bakımından analiz edildiğinde Tablo 6'daki sonuçlara ulaşılmaktadır. Sonuçlara göre çalışmaların \%31,57'sinde şehir belirtilmemiş ve \%12,28'i birden fazla şehirde yürütülmüştür. Şehir belirtilmiş olan araştırmaların 11'i i̇stanbul'da ve 4'ü Ankara'da yürütülmüştür. Araştırmanın yapıldığı diğer şehirler Nevşehir, Kayseri, Adana, Muğla, Burdur, Denizli, Eskişehir, Gaziantep, Samsun, İzmir, Uşak, Manisa ve Antalya'dır. 


\begin{tabular}{lrr} 
Tablo 6. Çalışmaların Yürütüldükleri Şehir Bakımından Dağılımı \\
Şehir & Frekans & Yüzde \\
İstanbul & 11 & 19,29 \\
Ankara & 4 & 7,01 \\
Nevşehir & 2 & 3,50 \\
Kayseri & 2 & 3,50 \\
Adana & 2 & 3,50 \\
Muğla & 2 & 3,50 \\
Burdur & 1 & 1,75 \\
Denizli & 1 & 1,75 \\
Eskişehir & 1 & 1,75 \\
Gaziantep & 1 & 1,75 \\
Samsun & 1 & 1,75 \\
İzmir & 1 & 1,75 \\
Uşak & 1 & 1,75 \\
Manisa & 1 & 1,75 \\
Antalya & 1 & 1,75 \\
Birden Fazla & 7 & 12,28 \\
Belirtmemiş & 18 & 31,57 \\
\hline TopLAM & 17 & 100
\end{tabular}

\section{7. Çalışmaların Yürütüldükleri Sektör Bakımından Dağılımı}

Çalışmalar yürütüldükleri sektör bakımından incelendiğinde en fazla çalışmanın sırasıyla eğitim (11), kamu (10) ve sağlık (10) alanında olduğu görülmektedir. Bunların dışında elektrik, ulaşım, sigorta, tarım, banka, deri, seramik, çimento, bilişim ve inşaat sektörü de yer almaktadır. Çalışmaların 8'i çeşitli sektörlerde yürütülmüş olup, araştırma makalesi olan 4 çalışmada sektör bilgisine yer verilmemiştir. 15 çalışma ise herhangi bir araştırma içermediğinden bu tabloya dahil edilmemiştir.

Tablo 7. Çalışmaların Yürütüldüğü Sektörler

\begin{tabular}{|c|c|c|}
\hline Sektör & Frekans & Yüzde \\
\hline Eğitim & 11 & 19,29 \\
\hline Kamu & 10 & 17,54 \\
\hline Sağlık & 10 & 17,54 \\
\hline Elektrik & 4 & 7,01 \\
\hline Ulaşım & 2 & 3,50 \\
\hline Sigorta & 1 & 1,75 \\
\hline Tarım & 1 & 1,75 \\
\hline Banka & 1 & 1,75 \\
\hline Deri & 1 & 1,75 \\
\hline Seramik & 1 & 1,75 \\
\hline Çimento & 1 & 1,75 \\
\hline Bilişim & 1 & 1,75 \\
\hline İnşaat & 1 & 1,75 \\
\hline Çeşitli & 8 & 14,03 \\
\hline Belirtilmemiş & 4 & 7,01 \\
\hline TOPLAM & 57 & 100 \\
\hline
\end{tabular}




\section{8. Çalışmalarda Kullanılan Bağımlı ve Bağımsız Değişkenler}

Çalışmalar ele aldıkları değiş̧enler bakımından da sınıflandırılmıştır. Bu bölüme yalnızca öncel-sonuç ilişkisi ele alınan çalışmalar dahil edilmiştir (Örneğin öğretmen ve okul müdürlerinin değişime direnç düzeyini kıyaslayan bir çalışma bu tabloda "yok" başlığı altında ele alınmıştır). Bu bölümde amaç, değişim üzerinde etkili olan ya da değişimin etkilediği değişkenler bakımından yazının bir görünümünü elde etmektir. Bu bağlamda, çalışmalar inceledikleri bağımlı ve bağımsı değişkenler bakımından analiz edildiğinde, araştırmaların belirli bir değişken etrafinda toplanmadığı görülmektedir. Bağımsız değişkenlerden 8'i (planlı değişim, değişim, web tabanlı değişim yönetimi sistemleri, değişim yönetimi, değişim yönetimi algısı, bilişim teknolojilerinde değişim, değişim yönetimi yeterliliği, değişim süreci) direkt olarak değişim ile ilgilidir. Bağımlı değişkenler incelendiğinde ise 7 değişkenin (değişim başarısı, değişim yönetimi, değişime direnç, değişimin kabullenilmesi, değişim sürecindeki davranışlar, değişime yönelik tutum, değişime uyum) değişim ile ilgili olduğunu görülmektedir. Değişim ile ilgili bağımlı değişkenlerin daha ziyade çalışanlar (direnç, uyum, tutum ve kabul gibi) ile ilgili olduğunu söylemek mümkündür.

Tablo 8. Çalışmalarda Kullanılan Bağımlı ve Bağımsız Değişkenler

\begin{tabular}{|lr|lr|}
\hline Bağımsız Değişken & Frekans & Bağımlı Değişken & Frekans \\
\hline Planlı değişim & 1 & Değişimin başarısı \\
Değişim & 2 & Kurum kimliği & 1 \\
Web tabanlı değişim yönetimi sistemleri & 1 & Değişim yönetimi & 1 \\
Değişim yönetimi & 2 & İşletme karlılığı & 3 \\
Değişim yönetimi algısı & 1 & Motivasyon & 1 \\
Transformasyonel liderlik & 2 & Teknoloji & 1 \\
Bilişim teknolojilerinde değişim & 1 & Rekabet koşulları & 1 \\
Değişim yönetimi yeterliliği & 1 & Verimlilik & 1 \\
Değişim süreci & 1 & İş doyumu & 1 \\
Duygusal tepki & 1 & Örgütsel çiftyönlülük & 1 \\
Risk algısı & 1 & Çalışanlar üzerindeki etkiler & 1 \\
Sonuç beklentisi & 1 & Finansal performans & 1 \\
Yönetim desteği & 1 & Değişime direnç \\
Örgüte güven & 1 & Değişimin kabullenilmesi & 1 \\
Örgütsel iletişim & 2 & Değişim sürecindeki davranışlar & 1 \\
İç motivasyon & 1 & Değişime yönelik tutum & 1 \\
Yönetim birimine uzaklık & 1 & Değişime uyum & 1 \\
Örgüte bağlılık & 1 & Yok & 2 \\
Risk alma & 1 & & 1 \\
Ödül sistemi & 1 & & 56 \\
Yok & 56 & & \\
& & & \\
& & & \\
\end{tabular}

\section{9. Çalışmalarda İncelenen "Değişim"e İlişkin Değişkenler}

Bağımlı ve bağımsız değişkenler "değişim"i içermeleri bakımından ele alındıklarında Tablo 9 ortaya çıkmaktadır. Bu tabloya göre örneklem dahilinde araştırmalarda "değişim"e ilişkin 12 farklı değişken ele alınmıştır. Bu değişkenlerden planlı değişim, değişim yönetimi, değişim yönetimi yeterliliği, değişim süreci ve değişim başarısı direkt olarak "değişim yönetimi" uygulamaları ile ilgili iken, değişim yönetimi algısı, değişime direnç, değişimin kabullenilmesi, değişim sürecindeki davranışlar, değişime yönelik tutum ve değişime uyum değişkenleri "değişim yönetimi" uygulamalarının beşeri boyutuna odaklanmaktadır. Bu anlamda değişim yönetimi uygulamalarını ele alan çalışmaların beşeri boyutunu ele alan çalışmalardan daha fazla olduğu sonucuna ulaşmak mümkündür. 
Tablo 9. Değişime iliş̧kin Değişkenler

\begin{tabular}{|l|l|r|}
\hline & Bağımsız Değişken & \multicolumn{2}{|l|}{ Frekans } \\
\hline 1 & Planlı değişim & 1 \\
\hline 2 & Değişim & 2 \\
\hline 3 & Değişim yönetimi & 5 \\
\hline 4 & Değişim yönetimi algısı & 1 \\
\hline 5 & Değişim yönetimi yeterliliği & 1 \\
\hline 6 & Değişim süreci & 1 \\
\hline 7 & Değişimin başarıı & 1 \\
\hline $\mathbf{8}$ & Değişime Direnç & 1 \\
\hline $\mathbf{9}$ & Değişimin kabullenilmesi & 1 \\
\hline $\mathbf{1 0}$ & Değişim sürecindeki davranışlar & 1 \\
\hline $\mathbf{1 1}$ & Değişime Yönelik Tutum & 2 \\
\hline $\mathbf{1 2}$ & Değişime Uyum & 1 \\
\hline
\end{tabular}

\subsection{Değişim Yönetimini Konu Alan Çalışmaların Sonuç İfadelerinin Analizi}

Bu çalışma kapsamında incelenen 72 çalışmanın 25'i bir kurumda gerçekleşen bir değişim sürecini incelemiştir. Bu 25 araştırmanın 14'ü tez ve 11'i araştırma makalesinden oluşmaktadır. Bir değişim modeli önerisi sunmak için değişim sürecinden geçmiş olan ve bu süreci deneyimlemiş olan kurumların tecrübe ve önerilerinden yararlanmanın anlamlı olacağı düşüncesiyle, bu araştırmaların bulguları, değişimin başarısını etkileyen unsurlar bakımından irdelenmiştir. Öncelikle incelenen tüm çalışmalarda olduğu gibi sonuç ifadeleri titizlikle derlenmiştir. Ardından bu ifadeler arasında değişim sürecinde başarının koşulu olduğu ifade edilen, ya da değişim sürecinde dikkat edilmesi gereken unsurlar olarak tanımlanmış ifadeler özenle seçilmiştir. 25 araştırmanın 2'sinde bu yönde ifadelere yer verilmediği görülmüştür. Bu 2 çalışmada yalnızca değişimin kurum açısından sağladığı fayda ve yol açttğı geliş̧melere değinilmiştir. Geri kalan 23 çalışmada, değişimin başarı faktörü olarak ifade edilen toplamda 122 ifadeye ulaşılmıştr. Bu ifadelerin anlam bakımından benzer olanlarının bir araya getirilmesiyle toplamda 8 ana başlık (tema) ortaya çıkmıştır. Bu başlıklar tekrar sıklıkları ile birlikte Tablo $10^{\prime}$ da sunulmaktadır. 12 ifade bu 8 başlıktan biri altında değerlendirmeye uygun bulunmadığından kapsam dışı bırakılmıştır.

Tablo 10. Sonuç Ifadelerinden Ortaya Çıkan Temel Başlıklar

\begin{tabular}{|l|l|r|}
\hline & TEMA & Frekans \\
\hline $\mathbf{1}$ & Iletişim & $\mathbf{4 0}$ \\
\hline & Etkin Iletişim & 13 \\
\hline & Görüş ve Önerileri Almak & 10 \\
\hline & Eğitim & 10 \\
\hline & Ön Bilgilendirme Toplantısı & 7 \\
\hline $\mathbf{2}$ & Potansiyel Direnişçiler & 18 \\
\hline & Kademe, eğitim, deneyim ve yaş azaldıkça direniş artmaktadır & 9 \\
\hline & Direnişle başetme stratejileri: işbirliği ve anlayış & 9 \\
\hline $\mathbf{3}$ & Insan Kaynakları & 8 \\
\hline $\mathbf{4}$ & Liderlik & 7 \\
\hline $\mathbf{5}$ & Paylaşınlan Vizyon & 7 \\
\hline $\mathbf{6}$ & Teşvik & 7 \\
\hline $\mathbf{7}$ & Değişim Ekibi & 5 \\
\hline $\mathbf{8}$ & Değişim Kültürü & 4 \\
\hline
\end{tabular}


Tablo 10 'da yer alan ilk 8 tema değişim uygulamalarında dikkat edilmesi gereken temel unsurlara işaret etmekte ve birbirine benzer ifadelerin bir araya gelmesinden oluşmaktadır. Illetişim ve potansiyel direnişçiler temaları, kendi içlerinde ayrıca alt boyutlara ayrılmışlardır. Bu alt boyutlar dikkat çekici şekilde ayrıştı̆ından ayrıca belirtilmiştir.

Illetişim boyutu altında ortaya çıkan ilk alt boyut olan "etkin iletişim", değişimden sorumlu ekibin, çalışanlarla olan iletişime önem vererek, dürüst ve samimi bir iletişim tarzı benimsemeleri gerektiğini, mümkünse farklı kanallardan iletişim kurmaya olanak sağlayarak yalnızca formal iletişim kanalları ile sınırlı kalmamalarını önermektedir. Değişim ekibi ve çalışanlar arasında güven ve bağlılık esasına dayalı bir iletişimin kurulması ve çalışanların kendilerini ifade edebilecekleri bir alan bulabilmeleri önem taşımaktadır. Illetişimin alt boyutlarından ikincisi olan "görüş ve öneri almak" çalışanların fikirlerine başvurarak onların sürece katıımasını sağlamayı ifade etmektedir. Burada çalışanların önerilerini sunmasını sağlayıcı sistemlerin geliştirilmesi değişim sürecinin etkin şekilde yürütülmesine katkı sağlayacaktır. Üçüncü alt boyut olan "eğitim", değişen şartlarda çalışanın tedirgin olmasını önlemek bakımından donanımı arttıracak uygun eğitim programlarına katılımlarının sağlanmasıdır. Böylece değişim baskısı azalacak ve çalışanların yeni rol ve sorumluluklarına uyum sağlaması kolaylaşacaktır. Çalışanlara yapılan bu yatırım, çalışanlar tarafindan değişim sürecinin önemli bir parçası olduğu hissini uyandıracağından değişim uygulamalarını kolaylaştıracaktır. Son alt boyut olan "ön bilgilendirme toplantssı" ise değişim gerçekleşmeden önce ve süreç boyunca çalışanlara değişim yönetimi uygulamalarının anlatılmasını ifade etmektedir.

ìkinci boyut olarak ortaya çıkan "potansiyel direniş̧iler", araştırma bulgularında değişime direndiği gözlenen grupları ifade etmektedir. Araştırmaların bulgularına göre alt kademe çalışanları üst kademe çalışanlarına göre, eğitimsiz bireyler eğitimli olanlara göre, deneyimi düşük olan çalışanlar deneyimi yüksek olanlara göre ve yaşı daha genç olanlar daha yaşlı olanlara göre değişime direnme eğilimindedirler. Bu nedenle bu kesimle daha fazla iletişim kurulması ve değişimin gerekliliğinin daha detaylı şekilde anlatılması değişimin başarısı için önem taşımaktadır. "Potansiyel direniş̧̧iler" ile başa çıkmak için tehdit ve baskıdan uzak durulması ve mümkün olduğunca işbirliğine gidilmesi önerilmektedir. Bu bağlamda dikkate alınmadığını ve tehdit altında olduğunu hisseden direnişçiler daha şiddetli karşı koyma yöntemlerine başvurabileceklerinden, direniş̧̧ilerin varlığını kabul eden anlayışlı bir yaklaşımın, değişim yönetimi uygulamaları bakımından daha doğru bir yöntem olacağı görülmektedir.

"Insan kaynakları" teması, değişim sürecinde insan kaynakları birimine gerekli önemin verilmesi, insan kaynaklarının çalışan odaklı bir yaklaşım sergilemesi, değişim sürecinde çalışanların kariyer planlamasının göz ardı edilmemesi ve çalışanların değişim sürecine bağlııklarını arttırmak amacıyla kilit rol üstlenmesi gerektiğini ifade etmektedir. "Liderlik" teması değişim yönetimi sürecini yöneten kişinin, güçlü liderlik vasıflarına sahip karizmatik bir lider olması gerektiğini ve değişim sürecine öncülük etmesinin beklendiğini ifade etmektedir. Değişime ilişkin bilgilendirmenin değişim liderinden gelmesi ve liderin çalışanlarla direkt iletişim kurmasının çalışanların değişime inanma intimalini arttırdığı görülmektedir. "Paylaşılan vizyon" değişim sürecine uygun bir şekilde yeni vizyon tanımının yapılmasını ve çalışanlarla paylaşılmasını içermektedir. Firma ve çalışanların gelecek beklentilerinin uyumlaştrılması ile değişim süreci daha etkin bir şekilde gerçekleşmektedir. "Teşvik" boyutu çalışanların değişim sürecine katılımlarını sağlamak ve yönetimin takdirini ifade etmek için ödül sistemlerinin oluşturulmasıdır. "Değişim ekibi" temasında ise değişim yönetimi uygulamalarından sorumlu olacak grubun kimlerden oluşabileceğine ilişkin öneriler sunulmaktadır. Üst düzey yöneticiler, insan kaynakları departmanı, değişime maruz kalacak gruplardan seçilecek üyeler ve dışardan danışmanlık hizmeti alınacak kişiler bu gruba dahil edilebilecek taraflardır. "Değişim kültürü" teması değişimi destekleyen bir örgüt kültürünün inşa edilmesini ifade etmektedir. Bu bağlamda kültür adil uygulamaları desteklemeli, çalışanlara güvende olduklarını hissettirmeli ve değişim uygulamalarını kolaylaştırmalıdır.

\subsection{Değişim Yönetimi Uygulamalarında Başarı Faktörleri}

Tablo 10'da ortaya çıkan temalar, analiz edilen araştırmalarda değişim yönetimi uygulamalarının başarılı olması için gerekli olduğu ifade edilen unsurlardır. Bu anlamda değişim yönetimi uygulayıcısı iletişim, potansiyel direnişçiler, insan kaynakları, liderlik, paylaşılan vizyon, teşvik, değişim ekibi, değişim kültürü 
unsurlarına gerekli hassasiyetin gösterileceğinden emin olmalıdır. Tablo $10^{\prime}$ da bu temalar tekrar sıklıkları, yani araştırma sonuçlarınca kaç kez vurgu yapıldığına göre sıralanmıştır. Bununla beraber 8 tema incelendiğinde kapsam ve aşama olarak uygulama içerisinde uygun bir sıralamada olmadıkları görülmektedir. Daha anlaşılır şekilde ifade edilecek olursa, iletişim unsurunun önemli olması değişim sürecinde ilk önce çalışanlara gerekli eğitimlerin verilmesini ve daha sonra vizyon ifadesinin oluşturulacağı anlamına gelmemektedir. Tablo 10' da çıkan sonuçlar uygulama basamakları açısından anlamlı olacak şekilde yeniden düzenlenecek olursa;

1. Yeni vizyon ifadesinin oluşturulması,

2. Değişim kültürünün oluşturulmaya başlanması,

3. Değişim liderinin belirlenmesi,

4. Değşim ekibinin kurulması,

5. İnsan kaynaklarının değişim ekibine destek olacak şekilde yapılandırılması,

6. Etkin iletişim için gerekli yapıların oluşturulması,

7. Değişime destek olanlar için ödül sistemlerinin oluşturulması,

8. Değişime direnme ihtimali olan tarafları doğru stratejiler ile kazanmak,

şeklinde adımlar halinde ifade edilebilir.

Analize dahil edilen araştırmalarda başarı kriterleri dışında değişim yönetiminin ne şekilde uygulanması gerektiğine dair adımların yer aldığı bir boyut daha ortaya çıkmıştır. Bu boyutta değişim sürecinde firmanın izlemesi gereken adımlar daha detaylı şekilde ifade edilmektedir. Aşağıda bu adımlara ilişkin detaylar yer almaktadır. Başarı faktörleri bu adımlarla birlikte göz önünde bulundurulduğunda değişim yönetimi sürecinde önemli unsurlar ve izlenecek adımlara ilişkin bütüncül bir rehbere ulaşmak mümkündür.

\subsection{Değişim Yönetimi Uygulama Aşamaları}

Mevcut çalışmada analiz edilen araşttrmaların sonuçlarında, değişim uygulama sürecinde izlenmesi gereken adımlara ilişkin ifadeler de yer almaktadır. Bu ifadelerin bir araya getirilmesi ile "değişim yönetiminde izlenmesi gereken aşamalar" şeklinde bir yapı ortaya çıkmaktadır. Bu bağlamda bu boyut benzer ifadeleri değil, birbirini izleyen bir süreci ifade etmektedir. Bu sonuç değişim uygulayıcıları bakımından pratik ve uygulanabilir bilgi sunması bakımından oldukça kıymetlidir.

Çalışmaya dahil edilen araştırmalarda değişim yönetimi uygulama aşamasında bazı hususlara dikkat çekilmiştir. Tablo 11'de sunulan ifadeler tek bir çalışmada vurgulanan basamaklar şeklinde olmayıp farklı çalışmalarda dikkat çekilen hususlar olması bakımından önemlidir. Böylece genel olarak değişim yönetimini uygularken hangi adımları izlemenin gerekli olduğuna dair bir uygulama şeması elde edilebilmiştir. Tablo 11 incelendiğinde değişim yönetimini uygulamak için öncelikle firmanın kendisini ve konumu iyi tanıması gerektiği ortaya çıkmakta ve bunun için SWOT analizi, iş süreçlerinin analizi ve görev tanımlarının yapılması gibi yöntemler önerilmektedir. Ardından firmada geliştirilebilecek yani değişim sürecinden faydalanabilecek alanların belirlenmesi aşaması gelmektedir. Değişim sürecinin ana hatlarının belirlenmesi, başarı sağlamak için yöntem ve amaçların belirlenmesi ve firmanın değişim sonucunda varacağı nihai hedefin tanımlanması ile değişimin ne şekilde uygulanacağının ortaya koyulması gereklidir. Eski yapı değişime hizmet etmeyeceğinden, yapının değişime uygun hale getirilmesi ile değişim süreci desteklenmelidir. Uygulanacak değişimin mümkünse pilot bölgede test edilmesi, tüm firmayı kapsamadan önce meydana gelebilecek aksaklıkların öngörülmesi bakımından önemlidir. Ancak bu uygulama her değişim yönetimi uygulamasında mümkün olamayabilir. Değişim uygulamalarının sürekli olarak izlenmesi, ilerlemenin, elde edilen gelişmelerin ve ortaya çıkan sorunların tespiti ve bunlara hızlıca müdahale edilmesi bakımından hayati bir önem taşımaktadır. Değişim yönetimi gerçekleştikten sonra personelin yeni duruma uygun pozisyonlara yerleştirilmesi ve mevcut durum kurumsallaşana dek değişim yönetiminin sona ermediğini hissettiren bir ekibin sürecin takipçisi olmasıyla, değişim yönetimi uygulamaları tamamlanmış olacaktır. Tüm bu süreçte 
değişim yönetimi uygulamalarının uzun vadede sonuç veren ve zaman alan uygulamalar olduğu unutulmamalıdır.

Tablo 11. Değişim Yönetimi Uygulama Aşamaları

\begin{tabular}{|l|l|}
\hline & Değişim Yönetim Uygulama Aşamaları \\
\hline 1 & $\begin{array}{l}\text { SWOT analizi, iş süreçlerinin analizi ve yapılabilecek değişikliklerin tespiti ile firmanın } \\
\text { kendisini tanıması ve durum tespitinin yapılması. }\end{array}$ \\
\hline 2 & Tüm görev tanımları ve iş süreçlerinin ayrıntılı el kitapları haline getirilmesi. \\
\hline 3 & $\begin{array}{l}\text { Tüm iş süreçleri, örgüt ve yönetim yapısını gözden geçirerek gelişim fırsatlarının } \\
\text { belirlenmesi. }\end{array}$ \\
\hline 4 & Değişim sürecinin ana hatlarının belirlenmesi. \\
\hline 5 & $\begin{array}{l}\text { Değişim sürecinde başarı için açıkça tanımlanmış yöntem ve ölçülebilir amaçların ortaya } \\
\text { koyulması. }\end{array}$ \\
\hline 6 & Değişim faaliyetlerinin firmayı ulaştıracağı nihai hedefin belirlenmesi. \\
\hline 7 & Yeni stratejiler doğrultusunda yeni örgüt yapısının düzenlenmesi. \\
\hline 8 & Mümkünse değişim uygulamalarının öncelikle pilot bölgede test edilmesi. \\
\hline 9 & Değişim sürecinin sürekli izlenmesi için değerlendirme sistemlerinin geliştirilmesi. \\
\hline 10 & Değişim sürecinin, revize etmek ve düzeltmek amacıyla sürekli izlenmesi. \\
\hline 11 & Değişim sürecinde ortaya çıkan sorunların hızlı bir şekilde çözülmesi. \\
\hline 12 & Değişim sonunda personelin kendilerine uygun bölümlere yerleştirilmeleri. \\
\hline 13 & $\begin{array}{l}\text { Değişim sürecinin sonunda değişimin kurumsallaşmasını sağlayacak bir ekibin sürece } \\
\text { devam etmesi. }\end{array}$ \\
\hline 14 & $\begin{array}{l}\text { Değişim yönetimi uygulamaları sonuçlarının uzun zaman gerektirdiği ve uzun vadede } \\
\text { daha iyi sonuçlar verdiğinin unutulmaması. }\end{array}$ \\
\hline
\end{tabular}

\subsection{Değişim Yönetimi Uygulaması için Model Önerisi}

Tablo 11'deki ifadeler incelendiğinde değişim yönetimi uygulamasında izlenecek 14 adımın başlık ve alt başlıklar şeklinde belirli bir yapıyı ortaya koyduğunu anlamak mümkündür. Bu 14 adım uygulama basamakları şeklinde bir model olarak ortaya koyulacak olursa;

1. Değişim gerçekleşmeden önce firmanın kendini durumunu tespit etmesi.
a. SWOT analizi
b. işs süreçlerinin analizi
c. Görev tanımlarının yapılması
d. Mevcut örgüt yapısının belirlenmesi
e. Mevcut yönetim yapısının belirlenmesi
f. Firmada değişim ve gelişime açık firsat alanlarının belirlenmesi

2. Değişimin ana hatlarının belirlenmesi
a. Değişimin başarısı için gerekli yöntemlerin belirlenmesi
b. Değişimin başarısı için ölçülebilir amaçların belirlenmesi
c. Değişim uygulamalarından beklenen nihai hedefin tanımlanması
d. Yeni stratejiler doğrultusunda gerekli yapının belirlenmesi
e. Mümkünse değişim uygulamalarının pilot bölgede test edilmesi

3. İzleme 

a. Değişim sürecini izlemek için değerlendirme sistemlerinin geliştirilmesi
b. İzleme sonucunda gerekli düzeltme ve revizelerin yapılması
c. Ortaya çıkan sorunlara ivedilikle müdahale edilmesi ve çözüme ulaştıılması

4. Sabitleme

a. Çalışanların yeni yapıda uygun pozisyonlara yerleştirilmesi

b. Değişimin kurumsallaşmasından sorumlu bir ekibin sürecin takipçisi olması.

Sonuç olarak değişim yönetimi uygulama aşamalarına ilişkin bulgular, uygulama sürecinde 4 temel adımın varlığını ortaya koymuştur. Bunlar mevcut durumun tespiti, değişimin ana hatlarının belirlenmesi, izleme ve sabitleme aşamalarıdır.

\section{Sonuç ve Tartş̧ma}

Bu araştırmanın temel amacı, Türk yazınında yer alan çalışmaların bulguları doğrultusunda bir değişim yönetimi modeli önererek, alanla ilgilenen araştırmacı ve uygulamacılara değişim yönetimi uygulama süreci hakkında detaylı bilgi sunmaktır. Bu amaçla 10 doktora ve 31 yüksek lisans tezi olmak üzere toplamda 41 tez ve 31 makale detaylı bir şekilde analiz edilmiştir. Araştırmalar yıl, yöntem, ölçek, geçerlilik ve güvenilirlik, şehir, sektör, bağımlı ve bağımsız değişken ve sonuç ifadeleri bakımından detaylı bir şekilde incelenmiştir. Değişim yönetimi alanında yapılan araştırmalar 1996 yılında başlamış olup, 1999 yılından günümüze kadar kesintisiz şekilde devam etmiş ve en fazla çalışma 8 araştırma ile 2004 yılında yapılmıştır. Örneklem dahilindeki araştırmaların çoğunda nicel yöntemin kullanıldığı görülmektedir. Araştırmalarda kullanılan ölçekler incelendiğinde, araştırmaların çoğunda kullanılan ölçeklerin, araştırmacının kendisi tarafindan geliştirildiği görülmektedir. Geçerlilik ve güvenilirlik analizine ilişkin bilgilerin yer aldığı çalışmaların çoğunda bu analizin araştırmacının kendisi tarafindan yapıldığı görülmektedir. Araştırmanın yürütüldüğü şehre göre bir sınıflandırma yapıldığında, araştırmaların büyük kısmının İstanbul'da gerçekleştirildiği, araştırmaların yürütüldüğü sektörler incelendiğinde ise en fazla eğitim, kamu ve sağlık sektörlerinde araştırma yapıldığı görülmektedir. Araştırmaların bağımlı ve bağımsız değişkenleri analiz edildiğinde, belirli bir değişken etrafinda toplanmadıkları, ancak değişime ilişkin toplamda 12 farklı değişkenin araşttrma konusu yapıldığı görülmektedir.

İncelenen araştırmalardan 14 tez ve 11 makalenin bir değişim sürecini ele aldıkları görülmüştür. Bu 25 çalışmanın sonuç ifadeleri değişim yönetimi uygulamalarının başarı kriterleri bakımından incelenmiş ve toplamda 122 ifadeye ulaşılmıştır. Bu ifadeler iletişim, potansiyel direnişçiler, insan kaynakları, liderlik, paylaşılan vizyon, teşvik, değişim ekibi, değişim kültürü olmak üzere toplamda 8 tema etrafinda birleşmiştir. Bu 8 temanın dışında ayrıca değişim yönetimi uygulama aşamaları da tespit edilmiştir. Bu aşamalar; öncelikle firmanın mevcut durumunu tespit etmesi, ardından değişimin ana hatlarının belirlenmesi, değişim sürecinin sürekli izlenmesi ve son olarak değişim uygulamalarının sabitlenmesi şeklindedir.

Elde edilen bulgular bir arada incelendiğinde, Pitt vd. (2001)'nin iletişim ve değişimin birbirinden ayrılmaz bir bütün oldukları görüşlerine uygun olarak değişim yönetimi uygulamalarının başarısı için 'çalışanlarla iletişim kurmanın' en önemli unsur olarak ortaya çıktığı görülmektedir. Değişim yönetimi uygulamalarından etkilenecek olan çalışanların değişim süreci başlamadan önce ve devamında sürekli olarak bilgilendirme toplantıları ile süreçten haberdar edilmesi, çalışanların kendi fikir ve önerilerini ortaya koymalarını sağlayacak çeşitli iletişim kanalları geliştirerek bu fikri ve önerilerin dikkate alınması, çalışanlarla tüm süreç boyunca samimi ve etkin iletişimin sağlanması ve son olarak çalışanların yeni rol ve sorumluluklarına uyum sağlamaları için yeni bilgi ve becerilerle donanmalarını sağlayacak eğitimlere katılmaları değişim yönetiminin başarıya ulaşma ihtimalini arttıracaktır. Bu süreçte, yeni duruma uygun vizyon ifadesinin hazırlanarak çalışanlar tarafindan benimsenmesinin sağlanması, değişim yönetimi uygulamalarını kolaylaştıracak bir örgüt kültürünün yerleştirilmesi, değişimden sorumlu olacak doğru bir liderin seçilip, uygun bir ekibin oluşturulması, insan kaynaklarının kilit rolünden uygun şekilde yararlanmak ve ödül sistemleri ile çalışanların değişime destek olması yönünde motive edilmeleri ile birlikte değişim yönetimi uygulamalarının etkinliği arttrılabilecektir. Değişime direnme intimali olan tarafların önceden tespit edilmesi, bu yönde ilk 
aşamadan itibaren gerekli önlemlerin alınabilmesini sağlayacaktır. Bu araştırmanın bulguları doğrultusunda kıdem, yaş, deneyim ve eğitim azaldıkça değişime direnme ihtimalinin arttı̆̆ını bilmekteyiz. Bu grupların daha fazla bilgilendirilmesi ve bu guruba daha anlayışla yaklaşılması, onların da değişim sürecine uyum sağlamlarını kolaylaştıracaktır.

Değişim yönetimi uygulamalarında belirlenen başarı faktörleri Oakland ve Tanner'ın (2007) araştırma bulguları ile benzerlik göstermektedir. Oakland ve Tanner (2007), değişim yönetimi alanındaki yapılan araştırmaları inceleyerek bazı temel başlıklar belirlemişlerdir. Bunlar; liderlik değişimin belirlenmesi, insanlar ve öğrenme sürecidir. Bu başlıklardan "liderlik" mevcut çalışmada da ortaya çıkan liderlik boyutu ile uyumludur. Yine mevcut çalışmada çalışan boyutunu ifade eden potansiyel direnişçiler ve yine çalışanların değişim sürecine adapte edilmesini sağlayan teşvik boyutu, Oakland ve Tanner'ın (2007) çalışmasında ortaya çıkan "insanlar" boyutu ile uyumludur.

Manning (2012) ise değişim yönetiminde kilit başarı temalarını stratejik düşünme, liderlik, görev yönetimi, ilişkiler ve kaynaklar olarak ele almaktadır. Bu boyutlar mevcut çalışmada sırasıyla; paylaşılan vizyon, liderlik, değişim ekibi, iletişim unsurlarına karşılık gelmektedir. Para, teknik bilgi ve uzmanlık gibi unsurları içeren kaynaklar boyutu ise mevcut çalışmada bir başarı unsuru olarak ortaya çıkmamıştır.

Jorgensen'in (2009) araştırma bulgularına göre değişimin başarı unsurları; üst yönetimin desteği, dürüst ve zamanında iletişim ve değişimi destekleyen bir kültürün varlığıdır. Bu unsurlardan üst yönetimin desteği mevcut araştırmada ortaya çıkmamış olan bir boyuttur. İletişim ve kültür ise çalışmamızın sonuçları ile paralellik göstermektedir. Bununla birlikte Jorgensen'in (2009) araştırmasında 3, mevcut çalışmada ise 8 başarı unsuru tanımlanmıştır.

Mevcut araştırmanın ikinci bulgusu olan değişim yönetimi uygulaması için önerilen modelin ilk aşaması ise öncelikle değişim gerçekleşmeden önce, firmanın kendi mevcut durumunu tespit etmek amacıyla SWOT analizi, iş süreçlerinin analizi, örgüt ve yönetim yapısının ve gelişime açık firsat alanlarının belirlenmesini içermektedir. İkinci adım değişimin ana hatlarının belirlenerek, değişim sürecinde kullanılacak yöntem, ulaşılacak amaç ve uygun yapının tespit edilmesini içermektedir. Üçüncü aşama olan izleme aşamasında değişim uygulamalarının gelişmelerini izlemeye imkan verecek bir değerlendirme sisteminin oluşturulması ve sürekli izleme sonucunda gerekli düzeltmelerin yapılarak sorunlara müdahale edilmesini içermektedir. Son aşama ise, değişimin sabitlenmesi için değişim uygulama süreci bittikten sonra bile sürecin takipçisi olacak ekibin belirlenmesi ve yeni yapının kurumsallaşmasına ilişkin çabaları içermektedir.

Değişim yönetimi modeli, Lewin'in (1951) modeli ile kıyaslanacak olursa araştırmacı tarafindan önerilen "çözme-değişim-yeniden dondurma" modeline karşılık "durum tespiti-değişimin planlanmasıizleme-sabitleme" modelinin ortaya çıktığını söylemek mümkündür. Bu bakımdan yalnızca son aşama olan "yeniden dondurma" ile "sabitleme" aşamalarının benzer olduğu görülmektedir.

Bulgular Kotter (1995)'ın modeli ile kıyaslanacak olursa (1. bir ivedilik duygusu oluşturmak, 2. güçlü bir rehberlik koalisyonu biçimlendirmek, 3. bir vizyon yaratmak, 4. vizyonu iletmek, 5. diğerlerine vizyona göre hareket etme yetkisi vermek, 6. kısa vadeli kazanımları planlamak ve oluşturmak, 7. iyileştirmeleri pekiştirmek ve daha fazla değişim yaratmak, 8. yeni yaklaşımları kurumsallaştırmak), kısa vadeli kazanımları planlamak ve oluşturmak aşamasının mevcut çalışmada ortaya çıkan modelin 2. basamağı olan "değişimin ana hatlarının belirlenmesi"ne denk geldiği, 8. basamağın da mevcut çalışmanın 4. aşaması olan "sabitleme" ye karşılık geldiği görülmektedir. Bulguların kıyaslanması sonucunda mevcut çalışama ile diğer araştırmalar arasında büyük ölçüde benzerliklerin bulunmaması, önerilen modelin farklı unsurlardan oluşan kendine özgü yeni bir model olduğunu göstermektedir.

Araştırma bulguları değişim sürecinde başarıya katkı sağlayan faktörlerin tespiti ve değişim yönetimi uygulamaları için 4 adımlık bir model önerisi ortaya koymaktadır. Bu bulgular, Türkiye'de uygulanmıs olan değişim yönetimi çalışmalarından elde edilen tecrübe ve sonuçları yansıtmak bakımından önem taşımaktadır. Bu çalışmanın, hem araştırmacılara hem de uygulayıcılara pratik bilgi sağlamak bakımından, değişim yönetimi alanına önemli bir katkı sağlayacağı düşünülmektedir. Mevcut çalışma kapsamında incelenen 72 çalışmanın 
böylesine bir model önerisi içermemesi ve ortaya koyulan modelin uygulama içeren çalışmaların bütününden hareketle oluşturulması, bulguların önemli bir rehber niteliğinde olduğuna işaret etmektedir.

\section{Kaynaklar}

Alıç, M. (1990). Genel liselerde örgütsel değiş̧me ihtiyacı. Eskişehir: Anadolu Üniversitesi Yayınları. No:382.

Altındiş, M., Altındiş, S., \& Saylı, H. (2011). Sağlık profesyonellerinin değişim sürecindeki tutumlarını belirlemeye yönelik bir araştirma. ZKÜ Sosyal Bilimler Dergisi, 7(4), 75-93.

Burnes, B. (2003). Managing change and changing managers from ABC to XYZ. Journal of Management Development, 22(7), 627-642.

Edmonds, J. (2011). Managing successful change. Industrial and Commercial Training, 43(6), 349-353.

Ekinci, H. (2006). Bilgi teknolojilerinin rekabet açııından önemi ve değişim yönetimindeki etkilerine ilişkin yöneticilerin algılarını ölçmeye yönelik bir araştırma. Kocaeli Üniversitesi Sosyal Bilimler Enstitüsü Dergisi, 11(1), 54-70.

Fink, M., Frank, H., Gundolf, K., \& Kailer, N. (2014). Management of qualitative change in small and medium-sized enterprises: A kaleidoscope of theoretical and empirical research. Review of Managerial Science, 9(2), 219-224.

Gökmen, A. (2010). Yönetici değiş̧iminin işletme performansına etkisi. Organizasyon ve Yönetim Bilimleri Dergisi, 2(2), 11-17.

Güçlü, N., \& E Şehitoğlu, T. (2006). Örgütsel değişim yönetimi. Kazım Karabekir Eğitim Fakültesi Dergisi, 13, 240-254.

Hussey, D. (1998). Değişim yönetimi (Çev.: Ali Çimen). ìstanbul: Timaş Yayınları.

Illğan, A. (2008). Örgütsel değişim/ değişme. Milli Eğitim Dergisi, 177, 21-31.

Jørgensen, H.H., Owen, L., \& Neus, A. (2009). Stop Improvising change management. Strategy \& Leadership, 37(2), 3844.

Kang, S.P. (2015). Change management: Term confusion and new classifications. Performance Improvement, 54(3).

Koçel, T. (2003). İ̧̧letme yöneticiliği. 9. Baskı. Beta Basım. İstanbul.

Kotter, J.P. (1995). Değişimi yönetmek: Dönüşüm çabaları neden başarısız kalıyor?. Değişim Harvard Business Review. 2013. Optimist. İstanbul.

Manning, T. (2012). Managing change in hard times. Industrial and Commercial Training, 44(5), 259-267.

Oakland, J. S., \& Tanner, S. (2007). Successful change management. Total Quality Management \& Business Excellence, $18,1-2$.

Özmen, F. \& Sönmez, Y. (2007). Değişim sürecinde eğitim örgütlerinde değişim ajanlarının rolleri. Fırat Üniversitesi Sosyal Bilimler Dergisi, 17(2), 177-198.

Öztürk, Ü. (2001). Kriz dönemlerinde örgütsel değişim yönetimi: Teori E ve Teori O yaklaşımları. Çukurova Üniversitesi Sosyal Bilimler Enstitüsü Dergisi, 8(8), 238-248.

Paksoy, H.M., \& Özbezek, B.D. (2013). Örgütsel değişimde beşeri sermayenin rolü. Akademik Bakış, 6(12), 293-331.

Pitt, L., Murgolo-Poore, M., \& Dix, S. (2001) Changing change management: The intranet as catalyst. Journal of Change Management, 2(2), 106-114.

Sabuncuoğlu, Z., \& Tüz, M. (1995), Örgütsel psikoloji. Ezgi Kitapevi, Bursa.

Skogland, M.A.C., \& Hansen, G. K. (2017). Change your space, change your culture: Exploring spatial change management strategies. Journal of Corporate Real Estate, 19(2), 95-110.

Kara, H., Tokat, B., \& Kara, M.Y. (2013). A-B tipi kişilik özelliklerine sahip işgörenlerin olası bir örgütsel değişime yatkınıklarının araştırılması. Turkish Studies - International Periodical For The Languages, Literature and History of Turkish or Turkic, 8(8), 1973-1988.

Vardar, A. (2001). Bireysel ve kurumsal değişimde yeniden yapılanma stratejileri. İstanbul: Kariyer Yayıncılık. 


\section{Ekler}

\section{EK: Araştırma Kapsamında İncelenen Tez ve Makaleler İncelenen Makaleler}

Akın, A. (2010). Bilgi Çağı İşletmelerinde Yeni Örgütsel Yapılanma. İktisadi ve İdari Bilimler Dergisi, 17, 3-4. 221-238.

Altındiş, M., Altındiş, S., ve Saylı, H. (2012). Sağlık Profesyonellerinin Değişim Sürecindeki Tutumlarını Belirlemeye Yönelik Bir Araştırma. Uluslararası Yönetim İktisat ve İşletme Dergisi, 7(14), 75-93.

Ar, i̇. M. (2012). Türkiye'deki Havalimanlarının Etkinliklerindeki Değişimin İncelenmesi: 2007-2011 Dönemi İçin Malmquist-TFV Endeksi Uygulaması. Atatürk Üniversitesi İktisadi ve İdari Bilimler Dergisi, 26 (3-4). 143160.

Aydintan, B. (2004). Değişim ve yeniden yapılanmada başarılı bir örnek: Arçelik. Iktisat Isletme ve Finans, 19(220), 17-30.

Baştan, S. (2003). Yapay Zeka, Yeni iletişim Teknolojileri ve Örgütsel Değişim: Akıllı Örgüte Doğru. Yönetim ve Ekonomi 10, 1. 187-203.

Bostan, S., ve Ünal, A. K. (2016). Sağlıkta Dönüşüm Programı Hakkında Yönetici ve Çalışan Görüşlerinin Karşılaştırılması Üzerinden Değişime Direncin Ölçülmesi. Verimlilik Dergisi, (3), 55-74.

Büyükyılmaz, O. (2013). Bilgi Yönetimi Uygulamaları Kapsamında İnsan Kaynakları Yönetiminde Meydana Gelen Değişimler. Uluslararası İşletme ve Yönetim Dergisi 1, 1. ss. 83-99.

Çömez, P. (2012). Örgütlerde Değişim Yönetiminin Finansal Performans Üzerine Etkisi: Elektrik Sektörü Üzerinde Bir Uygulama. Finansal Araştırmalar ve Çalışmalar Dergisi, 3(7). 17-27.

Dik, E. (2005). Kamu Yararı Anlayışında Değişim Baskısı. Mustafa Kemal Üniversitesi Sosyal Bilimler Enstitüsü Dergisi, 2(4).

Dolaşır, S. (2005). Değişim Yönetimi ve Spor Örgütleri. SPORMETRE Beden Eğitimi ve Spor Bilimleri Dergisi, III (1) 11-15.

Ekinci, H. (2004). Yeni Rekabet Aracı Olarak Bilgi Teknolojileri ve Değişim Yönetimindeki Rolüne İlişkin Görgül Bir Araştrrma. C.Ü. Sosyal Bilimler Dergisi. 28, 1 23-34.

Ekinci, H. (2006). Bilgi Teknolojilerinin Rekabet Açısından Önemi ve Değişim Yönetimindeki Etkilerine Iliş̧in Yöneticilerin Algılarını Ölçmeye Yönelik Bir Araştırma. Kocaeli Üniversitesi Sosyal Bilimler Enstitüsü Dergisi. 11,1 54-70.

Erkmen, T. (2006). A study About Employees' Acceptance of Chance Practices in Organizations. Yönetim. Yıl, 55(17), 1-15.

Gökbunar, R., ve Ünal, A. G. (1999). Yönetimde Dinazorlaşma Sendromu ve Kamu Yönetiminde Değişim. iktisadi ve idari Bilimler Dergisi, 13, 1. 45-58.

Gökçe, F. (2004). Okulda Değişmenin Yönetimi. Uludağ Üniversitesi Eğitim Fakültesi Dergisi, 17(2). 211-226.

Gökçe, F. (2008). Değişimin Kavramsal Modelleri ve Değişim Sürecinde Eğitim Yöneticilerinin Yeterlikleri. Milli Eğitim Dergisi, 172, 237-252.

Güleş, H. K., ve Burgess, T. F. (2000). Günümüz İşletmelerinde Değişim Yönetimi: Yöntemler ve Uygulanabilirliği. Atatürk Üniversitesi İktisadi ve İdari Bilimler Dergisi, 14(1). 101-114.

Gündüz, , Y., ve Balyer, A. (2013). Yükseköğretim Örgütlerinde Değişim ve Yenileşmeye iliş̧kin Akademik Algılamalar. Electronic Journal of Social Sciences, 12(43). 47-66.

ilğan, A. 2008. Örgütsel Değişim/ Değişme. Milli Eğitim Dergisi. 177. 21-31.

İnce, M. (2005). Değişim Olgusu ve Örgütlerde İnsan Kaynakları Yönetiminin Değişen Fonksiyonları. Selçuk Üniversitesi Sosyal Bilimler Enstitüsü Dergisi, (14), 319-339. 
İraz, R. ve Şimşek, G. (2004). Örgütsel Değişimin Gerçekleştirilmesinde Liderliğin Rolü: Transformasyonel Liderlik Incelemesi. Sosyal Ekonomik Araşttrmalar Dergisi, 1(7), 99-117.

Kırılmaz, H., Bağış, M., Salim, B., ve Şimşir, İ. (2015). Sağlık Yöneticilerinin Değişim Sürercine Bakış Açılarını Belirlemye Yönelik Bir Araştırma. Uluslararası Yönetim İktisat ve İşletme Dergisi, 11(25), 91-113.

Mutlu, K.M. ve Kahraman Y, (2012). Değişim Yönetimi: Üniversite Öğrencilerinin İnanç Sistemlerindeki Değişimler. Yönetim ve Ekonomi. 19,2. 219-237.

Özmen, F., ve Sönmez, Y. (2007). Değişim Sürecinde Eğitim Örgütlerinde Değişim Ajanlarının Rolleri. Fırat Üniversitesi Sosyal Bilimler Dergisi, 17, 2, 177-198.

Özseven, M., Danisman, A., ve Bingöl, A. S. (2016). Kurumsal Değişim, Güç Mekanizmalari ve Direniş Taktikleri: Türk Sağlık Alanında bir Araştırma. METU Studies in Development, 43, 3, 779-811.

Pınar, i. (2006). Değişim Yönetimi Anlayışı Olarak Öğrenen Organizasyonlar. Marmara Üniversitesi Sosyal Bilimler Enstitüsü Dergisi, 7,25, 29-42.

Pira, A., ve Kocabaş, F. (2003). Örgütsel İletişim Açısından Değişim Mühendisliği. Kocaeli Üniversitesi Sosyal Bilimler Enstitüsü Dergisi, 5,1. 87-102.

Sezgin, O. B., Tolay, E., ve Sürgevil, O. (2016). Örgütsel Değiş̧im Sinizmi: Çalışanların Değiş̧ime Karşı Tutumlarının İncelenmesine Yönelik Nitel Bir Araştırma. Öneri Dergisi, 12,45. 411-438.

Şengül, R. (2015). Örgütsel Değişim Faktörü Olarak İnovasyon ve Kamu Yönetimi. Eskişehir Osmangazi Üniversitesi IïB Dergisi, 10, 2. 141-151.

Taş, A. (2009). Evaluation of Teachers' Perceptions Related to High School Principals' Behaviors About Change Management. Inonu University Journal of the Faculty of Education. 10, 2. 1-18.

Tezsürücü, D., ve Bursalıoğlu, S. A. (2013). Yükseköğretimde Değişim: Kalite Arayışları. Kahramanmaraş Sütçü İmam Üniversitesi Sosyal Bilimler Dergisi, 10,2. 97-108.

Tolay, E., Dalkılıç, O. S., ve Sezgin, O. B. (2017). Örgütsel Değişim Sinizmi: Ölçek Geliştirme, Güvenilirlik ve Geçerlilik Çalışması. Atatürk Üniversitesi İktisadi ve İdari Bilimler Dergisi, 31,1. 101-117.

Tunçer, P. (2011). Örgütsel Değişim ve Liderlik. Sayıştay Dergisi, 80, 57-83.

Ustasüleyman, T. (2010). Organize Sanayi Bölgesi İşletmelerinde Değişim Mühendisliği Çalışmalarına Yönelik Bir Araşttrma. İktisadi ve idari Bilimler Dergisi, 23, 1. 229-246.

Ünal, Ö. F. (2012). İnsan Kaynakları Profesyonelinin Değişim Yönetimi Rolleri: Değişim Ajanı Bağlamında Bir Değerlendirme. International Journal of Economic \& Social Research, 8,2. 83-105.

Yıldız, A. K. (2010). Kütüphanelerde Değişim Yönetimi Uygulamalarının CMML ve CMML-CS İle İzlenmesi: Marmara Üniversitesi Merkez Kütüphanesi Örneği. Türk Kütüphaneciliği, 24,2. 258-284.

Yıldız, K. (2012). Yöneticilerin Değişimi Yönetme Yeterlikleri. Abant İzzet Baysal Üniversitesi Sosyal Bilimler Enstitüsü Dergisi, 25,25. 177-198.

\section{İncelenen Tezler}

Akdemir, S. (2012). Kamu Çalışanlarının Organizasyonel Değişim Yönetimi Algısı ile iş Doyum Düzeyleri Arasındaki İlişkinin Incelenmesi: TRT Genel Müdürlüğü Örneği. Gazi Üniversitesi Eğitim Bilimleri Enstitüsü. Yayınlanmamış Yüksek Lisans Tezi. Ankara.

Akkan, E. (2013). 4+4+4 Eğitim Modelinin Değişim Yönetimi Bakımından İncelenmesi. Uşak Üniversitesi Sosyal Bilimler Enstitüsü. Yayınlanmamış Yüksek Lisans Tezi. Uşak.

Akyüz, M. (2014). Örgütlerde İnovasyon ve Değişim Yönetimi Hakkında Nitel Bir Araştırma. Okan Üniversitesi Sosyal Bilimler Enstitüsü. Yayınlanmamış Yüksek Lisans Tezi. İstanbul. 
Aksoy, i. (2005). Ilköğretim Okullarında Görev Yapan Öğretmenlerin, Okulda Değişim Yönetiminin Gerçekleştirilmesinde, Örgütsel Illetişimin Rolüne Iliş̧kin Algıları. Gazi Üniversitesi Eğitim Bilimleri Enstitüsü. Yayınlanmamış Yüksek Lisans Tezi. Ankara.

Barutçu, E. (2000). Örgütsel Değişim Yönetimi ve Denizli Tekstil İşletmelerinde Bir Uygulama. Selçuk Üniversitesi Sosyal Bilimler Enstitüsü. Yayınlanmamış Doktora Tezi. Konya.

Cenker, B. (2008). Illköğretim Okullarında Görev Yapan Öğretmenlerin, Okulda Değişim Yönetiminin Gerçekleştirlmesine Bakış Açılarının İncelenmesi. Yeditepe Üniversitesi Sosyal Bilimler Enstitüsü. Yayınlanmamış Yüksek Lisans Tezi. İstanbul.

Çalışkan, A. (2007). Organizasyonel Değişim Yönetimi ve Azerbaycan Cumhuriyeti'ndeki Türk Menşeli İşletmelerde Bir Uygulama. Süleymen Demirel Üniversitesi Sosyal Bilimler Enstitüsü. Yayınlanmamış Doktora Tezi. Isparta.

Çelebi, S. (2014). Kamu İşletmelerinde Değişim Yönetimi Modeli: İETT Uygulaması. Yıldız Teknik Üniversitesi Sosyal Bilimler Enstitüsü. Yayınlanmamış Yüksek Lisans Tezi. İstanbul.

Çiçek, F. (2007). Avrupa Birliği'ne Giriş Sürecinde KOBi’lerdeki Değişim Yönetimi: Gaziantep'de Bir Uygulama. Gaziantep Üniversitesi Sosyal Bilimler Enstitüsü. Yayınlanmamış Yüksek Lisans Tezi. Gaziantep.

Çömez, P. (2007). Değişim Yönetiminde Dönüştürücü Liderlik Davranışlarının Firma Performansına Etkileri Üzerine Bir Araştırma. Gebze Yüksek Teknoloji Enstitüsü Sosyal Bilimler Enstitüsü. Yayınlanmamış Yüksek Lisans Tezi. Gebze.

Dağ, S. (2010). Hemşirelerin Değişim Yönetimi İle İlgili Görüşlerinin Belirlenmesi. Haliç Üniversitesi Sağlık Bilimleri Enstitüsü. Yayınlanmamış Yüksek Lisans Tezi. İstanbul.

Düzel Dilden, B. (2010). Değişim Yönetimi Bağlamında Ast Üst Illişkisi: Adana TEiAŞ Örneği. Gazi Üniversitesi Sosyal Bilimler Enstitüsü. Yayınlanmamış Yüksek Lisans Tezi. Ankara.

Elalmış, A.B. (2008). Çalışma Hayatı ve Organizasyonlarda Değişim, Değişim Yönetimi ve Değişim Yönetimi Üzerine Örnek Bir Uygulama: Lafarge Türkiye Çimento Grubu. Gazi Üniversitesi Sosyal Bilimler Enstitüsü. Yayınlanmamış Yüksek Lisans Tezi. Ankara.

Emir, H.A. (2004). Kamu Yönetimi Bağlamında Değişim Yönetimi ve Yönetsel çevre Illişkisi. Muğla Üniversitesi Sosyal Bilimler Enstitüsü. Yayınlanmamış Yüksek Lisans Tezi. Muğla.

Güven, C. (2006). İşgörenlerin Değişim Yönerimi Algılama Düzeylerinin Belirlenmesi ve Kamuda Bir Uygulama. Gazi Üniversitesi Sosyal Bilimler Enstitüsü. Yayınlanmamış Yüksek Lisans Tezi. Ankara.

Güzel, T. (1996). Değişim Yönetimi ve Planlı Değişim. Uludağ Üniversitesi Sosyal Bilimler Enstitüsü. Yayınlanmamış Yüksek Lisans Tezi. Bursa.

Hazır, K. (2004). Organizasyonlarda Web Tabanlı eğişim Yönetimi: Bilgisayar Teknolojilerinin Örgütsel Değişime iliş̧kin Algılamaları Üzerine Etkileri Konulu Bir Araştırma. Dumlupınar Üniversitesi Sosyal Bilimler Enstitüsü. Yayınlanmamış Doktora Tezi. Kütahya.

Kalkan, S. (2015). Sağlık Kurumlarında Değişim Yönetimi ve Bilişim Teknolojilerinin Uygulanması. İstanbul Gelişim Üniversitesi Sosyal Bilimler Enstitüsü. Yayınlanmamış Yüksek Lisans Tezi. İstanbul.

Kuzubaşıoğlu (2008). Genel Liselerde Çalışan Öğretmenlerin Değişim Yönetimi Faktölerine illişkin Algılarının Okul Etkililiği Açısından Değerlendirilmesi. Marmara Üniversitesi Eğitim Bilimleri Enstitüsü. Yayınlanmamış Yüksek Lisans Tezi. İstanbul.

Koç, Z. (2014). Örgütsel Değişim, Değişim Yönetimi ve Örgütsel Davranışlar Üzerine Bir Örnek Uygulama. Bahçeşehir Üniversitesi Sosyal Bilimler Enstitüsü. Yayınlanmamış Yüksek Lisans Tezi. İstanbul.

Niğdelioğlu, N. (2007). Örgütsel Değisim Yönetimi ve Seramik Sektöründe Uygulaması. Dumlupınar Üniversitesi Fen Bilimleri Enstitüsü. Yayınlanmamış Yüksek Lisans Tezi. Kütahya. 
Oktay, H. (2004). Değişim Yönetimi ve Kurum Kimliği Üzerindeki Etkileri. Ege Üniversitesi Sosyal Bilimler Enstitüsü. Yayınlanmamış Yüksek Lisans Tezi. İzmir.

Olcay, B. (2010). Değişim Yönetiminde Örgütsel Güvenin Rolü ve Önemi ve Bir Araşttrma. Marmara Üniversitesi Sosyal Bilimleri Enstitüsü. Yayınlanmamış Yüksek Lisans Tezi. İstanbul.

Öztop, S. (2014). Kamu Çalışanlarının Örgütsel Değişim Yönetimi Uygulamalarına Yönelik Algısı. Süleymen Demirel Üniversitesi Sosyal Bilimler Enstitüsü. Yayınlanmamış Doktora Tezi. Isparta.

Özçelik, F.S. (2002). Organizasyonel Değişim, Değişim Yönetimi, Organizasyonel Değişimin Aktörleri ve Sigorta Sektöründe Bir Uygulama. Marmara Üniversitesi Sosyal Bilimleri Enstitüsü. Yayınlanmamış Yüksek Lisans Tezi. ìstanbul.

Sayda, V. (2015). Elektronik Belge Yönetimi Uygulamalarında Personel Farkındalığının Artırılması: Değişim Yönetimi Açısından Bir İnceleme. İstanbul Üniversitesi Sosyal Bilimler Enstitüsü. Yayınlanmamış Yüksek Lisans Tezi. İstanbul.

Sanrı, Ö. (2014). Denizcilik İşletmelerinde Örgütsel İletişimin Değişim Yönetimi Üzerine Etkisi ve Bir Örnek Olay Çalışması. Dokuz Eylül Üniversitesi Sosyal Bilimler Enstitüsü. Yayınlanmamış Doktora Tezi. İzmir.

Şigaher, H. (2001). Postmerger Integration The Ultimate Change Management Challenge. Marmara Üniversitesi Sosyal Bilimleri Enstitüsü. Yayınlanmamış Doktora Tezi. İstanbul.

Tetik, S. (2008). Değişim Yönetiminde Dönüştürücü Liderin Rolü. Celal Bayar Üniversitesi Sosyal Bilimler Enstitüsü. Yayınlanmamış Doktora Tezi. Manisa.

Tiryaki, V. (2011). Yerel Yönetimlerde Değişim Yönetimi Altındağ Belediyesi Örneği. İstanbul Üniversitesi Sosyal Bilimler Enstitüsü. Yayınlanmamış Yüksek Lisans Tezi. İstanbul.

Tunçer, P. (2011). Yerel Yönetimlerde Değişim Yönetimi ve Samsun Büyükşehir Belediyesi Alan Araştırması. Gazi Üniversitesi Sosyal Bilimler Enstitüsü. Yayınlanmamış Doktora Tezi. Ankara.

Tümer, G. (2004). Organizasyonlarda Değişim Yönetimi ve İnsan Kaynakları Boyutu. İstanbul Üniversitesi Sosyal Bilimler Enstitüsü. Yayınlanmamış Yüksek Lisans Tezi. İstanbul.

Türkyılmaz, F. (2009). Çalışanların Özdeğerlendirme, Değişim Yönetimi ve Örgütsel Bağlıık Algılarının Değerlendirilmesi. Dokuz Eylül Üniversitesi Sosyal Bilimler Enstitüsü. Yayınlanmamış Yüksek Lisans Tezi. İzmir.

Ünalan, N. (2016). Bir Eğitim Hatanesinde Hastane Bilgi Sistemleri Değişim Yönetimi İncelenmesi ve İyileştirme Önerileri. Kara Harp Okulu Savunma Bilimleri Enstitüsü. Yayınlanmamış Doktora Tezi. Ankara.

Yaman, Z. (2007). Organizasyonlarda Değişim Yönetimi ve İşletmelerde Değişim Yönetimi Uygulamalarının Etkileri Üzerine Bir Araştırma. Maltepe Üniversitesi Sosyal Bilimler Enstitüsü. Yayınlanmamış Yüksek Lisans Tezi. İstanbul.

Yavuz, K. (2013). Guidelines for Information Technologies Change Management in Turkey. Kadir Has Üniversitesi Fen Bilimleri Enstitüsü. Yayınlanmamış Yüksek Lisans Tezi. İstanbul.

Yıldız, A.K. (2009). Kütüphaneler için Değişim Yönetimi Modeli. Marmara Üniversitesi Türkiyat Araştırmaları Enstitüsü. Yayınlanmamış Doktora Tezi.

Yılmaz, E. (2004). Değişim Yönetimi ve Yeni Bir İletişim Aracı Olarak E-Learning. Marmara Üniversitesi Sosyal Bilimleri Enstitüsü. Yayınlanmamış Yüksek Lisans Tezi. İstanbul.

Yılmaz, E. (2010). Hasta Memnuniyeti Odaklı Değişim Yönetimi. Beykent Üniversitesi Sosyal Bilimler Enstitüsü. Yayınlanmamış Yüksek Lisans Tezi. İstanbul.

Yılmaz, A.K. (2012). Değişim Yönetimi Stratejilerinin Hemşireler Üzerindeki Etkileri: Bir Hastane Örneği. Dokuz Eylül Üniversitesi Sosyal Bilimler Enstitüsü. Yayınlanmamış Yüksek Lisans Tezi. İzmir.

Yılmaz, G. (2014). Dönüşümcü Liderliğin Örgütsel Değişim Yönetimi ve Örgütsel Çift Yeteneklilik Üzerindeki Etkileri. Dokuz Eylül Üniversitesi Sosyal Bilimler Enstitüsü. Yayınlanmamış Yüksek Lisans Tezi. İzmir. 